\title{
Multinational Oil Corporations Corporate Integrity Ethics and Sustainable Development in Niger Delta, Nigeria
}

\author{
Okoji Olufemi Onweazu ${ }^{1}$ \\ ${ }^{1}$ Department of Educational Management, Lead City University, Ibadan, Nigeria \\ Correspondence: Okoji Olufemi Onweazu, Department of Educational Management, Lead City University, \\ Ibadan, Nigeria. E-mail: femiokoji2008@yahoo.com
}

Received: January 30, 2012 Accepted: September 1, 2012 Online Published: September 28, 2012

doi:10.5539/jsd.v5n10p114 URL: http://dx.doi.org/10.5539/jsd.v5n10p114

\begin{abstract}
The Niger Delta region has become the mainstay of the Nigerian economy, the zone is also known for its gas, hydrocarbon and water resources. These rich natural endowments have, however, not translated into concrete development of the region. Rather, the region has a catalogue of human and infrastructural problems which have been largely unattended to while its resources are being exploited. Thus, this study examines if the operation of multinational oil corporations in Niger Delta complies with the principles of corporate integrity. The study adopted descriptive survey research design of ex- post facto. The instrument used in this research work was tagged Corporate Integrity and Sustainable Development Questionnaire (CISDQ). The research questions raised for the study were analysed with Mean and Standard Deviation statistical data.
\end{abstract}

Keywords: Corporate Integrity, micro and macro social responsibility, intervention programmes, commitment and moral maturity

\section{Introduction}

The Niger Delta region is Nigeria's economic heartbeat (Darah, 2001) and is situated to the south of the country. The region, rich with crude oil, which has become the mainstay of the Nigerian economy (Ekuerhare, 2002), the zone is also known for its gas, hydrocarbon and water resources. These rich natural endowments have however not translated into concrete development of the region. Rather, the region has a catalogue of human and infrastructural problems which have been largely unattended to while its resources are being exploited (Fubara, 2002). Consequently, the region is at present, averred to be very volatile as Multinational Oil Corporations especially in the oil industry have suffered increased aggression from host communities for their perceived ethical inconsistencies towards alleviating the numerous problems of the host communities. The situation is such that according to Darah (2001), these multinational oil corporations are perceived to represent imperial terror against the region. Multinational oil corporations have, over the years, exploited the widespread ignorance of the people of the region, the Niger Delta Environmental Survey of 1997 indicates that the people are becoming increasingly enlightened about their rights as citizens, in the same vein that they are becoming increasingly aware of how much is derived from their communities as oil revenues both for the government and the multinational oil corporations (Niger Delta Survey, 1992).

The corporate response of the multinational oil corporations to the socio economic problems in Niger Delta, Nigeria could be properly explained through two major concepts, these are micro and macro corporate social responsibility. The Macro response strategy of multinational oil corporations refers to indirect consequence of sudden and steep rises in revenue for extractive industries for the host country and society, such as the effect of oil revenues on corruption, human rights controversies and lack of democratic progress in developing countries (Skjaerseth et al., 2004). In contrast, micro response encompasses the immediate effects of the intervention programmes of the multinational oil corporations on the local communities and these include employment of the host community members in their corporations and provision of basic infrastructural facilities in their areas of operations to improve their living condition.

The distinction between macro and micro corporate social responsibility is, not clear cut since local corporate responses, such as employment of local people or building of new schools, can produce significant results with possible ramifications to the macro level. Nevertheless, there is a fundamental difference in the risk involved. Micro corporate social responsibility projects benefit both companies' reputation and community development. 
Whatever decision a multinational oil corporation decides to embark upon, it is obvious that the two strategies will benefit the oil corporation's reputation and the development of the host countries. However, a major criteria use for analyzing such corporate response is the level and degree of commitment, level of commitment refers to the extent to which oil corporations recognize and respond to demand for responsibility for developments on the macro level in host countries. Degree of commitment refers to the link between rhetoric and realities (Skjaerseth et al., 2004).

Development ethics is an effort to rethink the idea of development within the context of the failure of the project. The failure of the project starts from the misconception that development is mere economic growth and that it is completely a morally neutral concept. The deconstructive project of these new development ethicists seeks to emphasize that the idea of development is ethical. It maintains also that the idea is not universal but relative to societal preferences and value system. In this respect, it is the societal value that determines the concepts of development.

Finally, the development ethicists also affirm that mere economic growth that fails to translate into the realization of the common good is not only unsustainable but a "de-development", in the sense that the populace that needs the development cannot benefit from it (Owolabi et al., 2009).

\subsection{Multinational Oil Corporations Intervention Programmes, Corporate Integrity and Sustainability}

The intervention programmes of the multinational oil corporations can also be better explained through the concept of corporate integrity. Jones and Pollitt (1995) posit that there are three dimensions of integrity in business life and these include the personal, the corporate and the macro - economic. It is thus appropriate to conceptualise integrity as an organizational level concept since organizations are engaged in a web of relationships with stakeholders and are therefore bound by the ensuing expectations and agreed standards of operation (Kaptein \& Reenen, 2001). Integrity refers to strength which involves a reputation for truthfulness, honesty and conscientiousness (Ahiauzu, 2003). This definition focuses on three fundamental characteristic features that determine the level of trustworthiness of individuals or organizations. Thus, Werhane and Freeman (1997), in their definition of integrity emphasized the quality of moral self-governance at both the individual and group level. Integrity is rooted in moral convictions (Ejiofor, 1987) and is very important for corporate success. Secretan (2001) posits that corporations that build their cultures around integrity are likely to achieve a quantum leap in effectiveness. Thus, if the multinational oil corporations operating in Niger Delta Nigeria follow the principle of corporate integrity ethics, they will be able to reach out to the host communities in their area of operations and this will help them to maintain cordial relationship with the host communities.

For any multinational oil corporation that has attained moral maturity, its response to the expectations of its host community is not only determined by legal constraints or the desire to avoid sanctions. Neither is it solely determined by industry solidarity contract, but more so by a creative expression of self discipline and self control that is morally defined. Their approach to social responsibility is therefore anticipatory and preventive rather than reactive and retrospective (Ivancevich et al., 1997). Integrity, which is bounded by justice, dependability, and morally justifiable principles and values, therefore influences the multinational oil corporation's intervention to the developmental process in its host community (Ahiauzu, 2003).

Development is regarded, not as mere economic transformation, but rather as improvement in all aspects of life, without compromising the rights of others to achieve the same. It is in this respect that development is being seen as strongly related to democracy. The concept of developmental democracy has been coined to meet with this new aspiration. The concept refers to the strong relationship between the idea of development as improvement of human condition and the idea of democracy as involving the rights of the citizen to determine what constitutes genuine improvement of his condition. Democracy is indeed an ethical concept in the sense that it accepts that it is right and proper for all the citizens to participate in the process of development (Owolabi \& Owolabi, 2009). In this respect, the idea of development can be sustainable only if the people who need it define their needs and are active participants in the process of meeting those needs.

In essence, sustainable development is attainable only if it is democratic, that is, if the very people who are the objects of development freely define what they consider as development. The idea of genuine development as one that is democratic clearly underscores the ethical essence of development. The good life, as the early Greeks defined development, is not only the satisfaction 7 of the material needs but also the enhancement of the overall respect for the rights of all, which is the condition for the desired social order that is a necessity for the good life (Owolabi, 2009). Development, as the good life, involves material improvement no doubt, but it also demands that such material benefits should be enjoyed by all and not by a privileged few. It is in this respect that the ethical consideration is an imperative for development. 
The need for ethical consideration by the multinational oil corporations is necessary because of the realization that sustainable development cannot be attained unless we have a development ethics guiding our development project. This imperative of "development ethics" has been strongly advocated for by many Third World scholars from the Latin America countries, Asia and, recently, Africa (Owolabi et al., 2009). Paradoxically, this is due to the fact that in these developing areas, the more the project of development is seriously pursued the more we discover that we are moving far away from it. What is responsible for this inverse proportion between the rate of pursing development and that of its realization? Goulet (1998) asserted that the development project is not getting results because we often neglect the ethical dimension of development.

\subsection{Multinational Oil Exploration Activities and Environmental Effect in Niger Delta}

To a considerable extent, the geographical location and the resources of the Niger Delta region compelled the people of the region to a monothetic traditional occupation of fishing and farming (Akinbami, 2008). With the heavy presence of the oil exploration activities of the multinational oil corporations, this livelihood of the people have been severely destroyed (Oruwari, 2006). Besides, Abdullahi, (1994) asserts that as a result of the long neglect of the region by the Federal Governments of Nigeria and the nonchalant attitude of the companies operating in the area, development in the area is very slow.

The Niger Delta region is seen as perhaps the most environmentally fragile part of Nigeria (Aina, 2007). It is also generally known that the presence of hydrocarbons, particularly gas and oil, has made this part of the country the neglected goose that lays the golden eggs (Okoko, 1998). The region was reported by the World Bank in 1999 to have the agricultural potential of feeding the whole region (NDDC, 2003). However, Efemini (2002) asserted that the people of the Niger Delta are of the view that with the enormous wealth associated with their oil endowments, there is no justification for remaining at the present low level of development. Hence, the increasing demand by the people for a fair treatment towards the actualisation of their dream of accelerated and sustainable development (Zalik, 2004). These demands have taken several forms of agitations from non-violent to violent mass actions which have resulted in the disruptions of operations of the multinational oil corporations (Asawo, 2011).

\subsection{Objectives of the Study}

The study intends to assess the multinational oil corporations' corporate integrity ethics and sustainable development in Niger Delta Nigeria. The main objectives are to investigate the extent to which multinational oil corporations have enhanced the socio-economic development of the host communities through their intervention programmes. The study will examine the living conditions of the community members before the implementation of the sustainable development programmes and how these programmes have impacted on the standard of living of the host communities. The study will examine the extent to which the multinational oil corporations adhere strictly to the principle of corporate ethics and moral maturity in solving the environmental effect of the oil exploration in the region. Finally, through the findings, some recommendations will be proffered to the multinational oil corporations on how the sustainable development programmes will help to improve the socio-economic welfare of the host communities in Niger Delta region.

2.

\subsection{Methodology}

The descriptive survey research design of the ex-post facto type was adopted for the study. The population for the study comprised of the officials of the multinational oil corporations in Niger Delta, Nigeria. Random sampling technique was used to select 100 officials of multinational oil corporations, this comprised of 50 respondents from Total Exploration \& Production Nigeria Limited and 50 respondents selected from Exxon Mobil Producing Nigeria Unlimited. The instrument used for the research was the questionnaire tagged Corporate Integrity and Sustainable Development Questionnaire (CISDQ). It was a four point Likert rating scale of Strongly Agreed (SA), Agreed (A), Strongly Disagreed (SD), Disagreed (D). The structured questionnaire was made up of three sections: A - C.

Section A: Demographic Variables. This consisted of items measuring demographic characteristics of the respondents: age, sex, educational qualification and years of experience.

Section B: Measure of Attitude. This consisted of six self constructed items that measures the attitude of the host communities to the sustainable development programmes of multinational oil corporations. The measure of the attitude was validated and yielded Cronbach co-efficient of 0.79 . This shows that the instrument is highly reliable. 
Section C: Measure of Corporate Integrity. This consisted of seven items that were self constructed. This was validated and yielded Cronbach co-efficient of 0.83 . This confirms the reliability of the instrument

\subsection{Instruments}

The instruments used to collect data for this study was questionnaire, which was divided into three sections. Corporate Integrity and Sustainable Development Questionnaires (Section B and C consisted of 12 item scale that was arranged in Likert scale format: $\mathrm{SD}=$ strongly disagree, $\mathrm{D}=$ disagree, $\mathrm{A}=$ agree and $\mathrm{SA}=$ strongly disagree. A total of 130 questionnaires were administered, out of which 100 copies were properly filled. Frequency count, mean and standard deviation were used for data analysis.

3.

\subsection{Result and Discussion}

Section A (Demographic characteristics of respondents)

Out of the 100 respondents data analysed, 80 were males while 20 were females with a mean age of 45 years. 69 respondents had first degree, while 19 respondents had higher degree and 12 others had Ordinary National Diploma. This indicated that the officials of the multinational oil corporations are well educated because of their educational qualifications.

\section{Research Question 1}

Rq1: What are the attitudes of the host communities to the sustainable development programmes of the multinational oil corporations in Akwa lbom and Rivers state?

Table 1. The Table showing the result of the Attitude of the Host Communities to the Sustainable Development Programmes of Multinational Oil Corporations

\begin{tabular}{|c|c|c|c|c|c|c|c|}
\hline $\mathrm{S} \backslash \mathrm{N}$ & Statement & SD & $\mathrm{D}$ & A & SA & Mean & S.D \\
\hline 1. & $\begin{array}{l}\text { The community members are very } \\
\text { happy with the intervention projects } \\
\text { because they helped to enrich the } \\
\text { community members }\end{array}$ & $\begin{array}{c}21 \\
21.0 \%\end{array}$ & $\begin{array}{c}18 \\
18.0 \%\end{array}$ & $\begin{array}{c}32 \\
32.0 \%\end{array}$ & $\begin{array}{c}29 \\
29.0 \%\end{array}$ & 2.9600 & 1.1073 \\
\hline 2. & $\begin{array}{c}\text { The community members usually relate } \\
\text { well with the officials of multinational } \\
\text { oil corporations }\end{array}$ & $\begin{array}{c}12 \\
12.0 \%\end{array}$ & $\begin{array}{c}23 \\
23.0 \%\end{array}$ & $\begin{array}{c}34 \\
34.0 \%\end{array}$ & $\begin{array}{c}31 \\
31.0 \%\end{array}$ & 2.8400 & 1.0022 \\
\hline 3. & $\begin{array}{l}\text { The attitude of the members is not } \\
\text { negative because of the failure of } \\
\text { multinational oil corporations to } \\
\text { empower their youth }\end{array}$ & $\begin{array}{c}19 \\
19.0 \%\end{array}$ & $\begin{array}{c}27 \\
27.0 \%\end{array}$ & $\begin{array}{c}23 \\
23.0 \%\end{array}$ & $\begin{array}{c}31 \\
31.0 \%\end{array}$ & 2.6600 & 1.1121 \\
\hline 4. & $\begin{array}{l}\text { The community members have a } \\
\text { negative feeling towards the } \\
\text { multinational oil corporations because } \\
\text { of the marginalization by the oil } \\
\text { corporations }\end{array}$ & $\begin{array}{c}27 \\
27.0 \%\end{array}$ & $\begin{array}{c}18 \\
18.0 \%\end{array}$ & $\begin{array}{c}24 \\
24.0 \%\end{array}$ & $\begin{array}{c}31 \\
31.0 \%\end{array}$ & 2.5900 & 1.1900 \\
\hline 5. & $\begin{array}{l}\text { The community members are happy } \\
\text { because the programmes have improved } \\
\text { their standard of living }\end{array}$ & $\begin{array}{c}28 \\
28.0 \%\end{array}$ & $\begin{array}{c}21 \\
21.0 \%\end{array}$ & $\begin{array}{c}19 \\
19.0 \%\end{array}$ & $\begin{array}{c}32 \\
32.0 \%\end{array}$ & 2.5500 & 1.2092 \\
\hline
\end{tabular}

\subsection{Interpretation and Discussion}

Below is the rating of the attitude of the host community to the sustainable development programmes of the multinational oil corporations:

The community members are very happy with the sustainable development programmes because they helped to enrich the community members (Mean $=2.9600$ ) was ranked highest by mean scores. The findings revealed that multinational oil corporation officials claimed that the host communities were happy about the sustainable 
development programmes because they were enriched through the programmes contradict the opinion expressed by the traditional ruler of Akabite community in Rivers state.

In the Key Informant Interview conducted with the traditional ruler of Akabite on $23^{\text {rd }}$ of July, 2011, he said that the community were not happy with the sustainable development programme because the multinational oil corporations have impoverished the host community through the oil exploration and as such community members cannot catch fish in the stream.

The findings also contradict the view of Efemini (2002) who asserted that the people of the Niger Delta are of the view that with the enormous wealth associated with their oil endowments, there is no justification for remaining at the present low level of development

The findings of the study also revealed that the community members relate well with the officials of the multinational oil corporations which tallies with the opinion of village head in Ebanna community in Akwa lbom state. In the key informant interview conducted with the village head on $21^{\text {st }}$ of May, 2011. He asserted that though the community members were not happy with the officials of the multinational oil corporations but they have to maintain peaceful relationship with them since the community members are peace loving people. The finding also contradict the view of Asawo, (2011) who asserted that the issues that have given rise to oil corporations and community conflict include environmental degradation, underdevelopment of infrastructure, poverty and large scale unemployment.

The findings from the officials of the multinational oil corporations revealed that the attitude of the community members is not negative because of the failure of multinational oil corporations to empower their youth contradicts the assertion of Tuschl and Ejibunu (2007) who traced the frequent conflicts in Niger Delta to poverty and deprivation of the means of livelihood as a result of oil spills.

It was revealed in the findings that the community members have a negative feeling towards the multinational oil corporations because of the marginalization, this tallies with the view of Ogbogbo (2004) who pointed out that the resort to the use of force through the police has often resulted in straining the relationship between the multinational oil corporations and their host communities.

\section{Research Question 2}

To what extent have the Sustainable Development Programmes of Multinational Oil.

Corporations conform to the standard of corporate integrity, commitment and moral maturity.

\begin{tabular}{|c|c|c|c|c|c|c|c|}
\hline & & SD & $\mathrm{D}$ & $\mathrm{A}$ & SA & Mean & S.D. \\
\hline 1 & $\begin{array}{l}\text { Good corporate citizenship is absolutely necessary for } \\
\text { the sustenance of a healthy operating environment for } \\
\text { multinational oil corporations }\end{array}$ & $\begin{array}{c}2 \\
2.0 \%\end{array}$ & $\begin{array}{c}6 \\
6.0 \%\end{array}$ & $\begin{array}{c}13 \\
13.0 \%\end{array}$ & $\begin{array}{c}79 \\
79.0 \%\end{array}$ & 3.69 & .68 \\
\hline 2 & $\begin{array}{l}\text { Information management technique of the corporations } \\
\text { is important for the development of corporate integrity } \\
\text { competence with host communities }\end{array}$ & $\begin{array}{c}4 \\
4.0 \%\end{array}$ & $\begin{array}{c}1 \\
1.0 \%\end{array}$ & $\begin{array}{c}19 \\
19.0 \%\end{array}$ & $\begin{array}{c}76 \\
76.0 \%\end{array}$ & 3.67 & .70 \\
\hline 3 & $\begin{array}{l}\text { If the multinational oil corporations build the } \\
\text { intervention programmes around corporate integrity this } \\
\text { will improve their relationship with the host } \\
\text { communities }\end{array}$ & $\begin{array}{c}2 \\
2.0 \%\end{array}$ & $\begin{array}{c}4 \\
4.0 \%\end{array}$ & $\begin{array}{c}41 \\
41.0 \%\end{array}$ & $\begin{array}{c}53 \\
53.0 \%\end{array}$ & 3.45 & .67 \\
\hline 4 & $\begin{array}{l}\text { Corporate integrity capacity ensures that multinational } \\
\text { oil corporations view seriously its social responsibility } \\
\text { in the area of environmental protection }\end{array}$ & $\begin{array}{c}4 \\
4.0 \%\end{array}$ & $\begin{array}{c}16 \\
16.0 \%\end{array}$ & $\begin{array}{c}24 \\
24.0 \%\end{array}$ & $\begin{array}{c}56 \\
56.0 \%\end{array}$ & 3.32 & .89 \\
\hline 5 & $\begin{array}{l}\text { The corporate social responsibility response of the } \\
\text { multinational oil corporations to the host communities is } \\
\text { influenced by self discipline and self-control which is } \\
\text { morally defined }\end{array}$ & $\begin{array}{c}9 \\
9.0 \%\end{array}$ & $\begin{array}{c}8 \\
8.0 \%\end{array}$ & $\begin{array}{c}34 \\
34.0 \%\end{array}$ & $\begin{array}{c}49 \\
49.0 \%\end{array}$ & 3.23 & .94 \\
\hline 6 & $\begin{array}{l}\text { Corporate integrity which is bounded by morally } \\
\text { justifiable principles and values will enhance the oil } \\
\text { corporations to improve on the intervention programmes }\end{array}$ & $\begin{array}{c}5 \\
5.0 \%\end{array}$ & $\begin{array}{c}17 \\
17.0 \%\end{array}$ & $\begin{array}{c}36 \\
36.0 \%\end{array}$ & $\begin{array}{c}42 \\
42.0 \%\end{array}$ & 3.15 & .88 \\
\hline 7 & $\begin{array}{l}\text { Inability of the oil corporations to address the } \\
\text { environmental degradation which occur as a result of oil } \\
\text { exploration has affected corporate integrity, morality } \\
\text { and commitment }\end{array}$ & $\begin{array}{c}49 \\
49.0 \%\end{array}$ & $\begin{array}{c}31 \\
31.0 \%\end{array}$ & $\begin{array}{c}15 \\
15.0 \%\end{array}$ & $\begin{array}{c}5 \\
5.0 \%\end{array}$ & 1.76 & .89 \\
\hline
\end{tabular}


Good corporate citizenship is absolutely necessary for the sustenance of a healthy operating environment for multinational oil corporations (Mean $=3.69$ ) ranked highest. The finding tallies with (Eilbert \& Parket, 2001) who opined that oil exploration activities of the multinational oil corporations should not have negative effect on the environment where they operate. However, what operates presently in Niger Delta negates this finding because of the effect of the oil exploration activities of multinational oil corporations on the host communities in South - South Nigeria. This correlates with the assertion of Odoemena, (2011) who asserted that there has been a total disregard for the social, political, economic and environmental sensibilities of the Niger Delta peoples by the multinational oil corporations operating in the region. Since 1956, they have been adopting substandard practices thereby subjecting them to untold inhumanities and injustices.

The Information management technique of the corporations is important for the development of corporate integrity competence with host communities (Mean =3.67). This correlates with Henkin et al., (2000) who argue that conflict management is a communicative behaviour. This view stems from the belief that one way of changing peoples' perceptions is through effective communication. The importance of communication cannot be underestimated in the corporate integrity competence. Stressing on the importance of communication on corporate integrity, Fajana (2005) asserted that good communication convince workers that they have an important stake in company and thereby leads to increasing workers loyalty. This tallies with the findings because effective communication enhances oil corporations - community relationship

If the multinational oil corporations build the intervention programmes around corporate integrity this will improve their relationship with the host communities (Mean =3.45). This tallies with the assertion of (Ahiazu, 2005) who asserted that an important strategy that can be adopted to shore up corporate image and douse the tension that characterizes company-community conflict is to enhance an organization's communication competence. This however requires a corporate social audit, which enables the organization to reposition itself to attract long-term goodwill. Social audit in Fubara, (2002) view is a systematic attempt to assess business performance in terms of social issues.

The finding also correlates with the view of Upeh, (2005) that the principle of community involvement in decision making process, adoption of stricter domestic laws and stricter universal standards of corporate liability will encourage healthy relationship and sustainable business between the community and the oil companies by reducing frictions and associated human rights violations and by sustainable development of the community in order to compensate for its environmental and ecological degradation.

Corporate integrity capacity ensures that multinational oil corporations view seriously its social responsibility in the area of environmental protection (Mean $=3.32$ ).

This tallies with the assertion of Odoemena, (2011) that the issue of environmental sustainability cannot be overemphasized in the Niger-Delta as this is fundamental to the overall well being and the development of the area especially the well being of future generation which is an important aspect of environmental economics.

Furthermore, the finding tallies with Upeh, (2005) who asserted that the environmental harm must be connected to a substantive right in order to meet the requirement of international Human Rights law; the law must therefore be evolved to include environmental protection as a measure to improve people's lives through preservation of environment; an obligation for the international community.

The corporate social responsibility response of the multinational oil corporations to the host communities is influenced by self discipline and self-control which is morally defined (Mean $=3.23$ ). This finding negates the assertion of Fajana, (2005) that oil exploration activities in the Niger Delta have been associated with the destruction of indigenous forest reserves, socio- economic and cultural lives of the people in the region. The reason for this is that oil exploration environmental degradation and destruction of forest reserves, ecosystem and agricultural produce in the region is traceable to the effect of oil exploration in the region

Corporate integrity which is bounded by morally justifiable principles and values will enhance the oil corporations to improve on the intervention programmes $($ Mean $=3.15$ ). The finding correlates with the assertion of Asawo, (2011) that the integrity audit enables organizations enhance their moral awareness and character, which subsequently manifests in ethical conducts such as corporate truth-telling and transparency. The finding also correlates with Sklair, (2001) who opined that corporations are forced to be good corporate citizens because they operate within strict regulatory regimes imposed by local, national and international government authority. Corporate integrity capacity therefore ensures that the organization views seriously its social responsibility like environmental protection and infrastructural development of host community. 
Finally, inability of the oil corporations to address the environmental degradation which occur as a result of oil exploration has affected corporate integrity, morality and commitment (Mean $=1.76$ ). The finding correlates with Asawo, (2011) who asserted that oil corporations are expected to operate within stipulated legal and ethical frameworks in order to avoid any negative moral tag that will erode a healthy business environment.

4.

\subsection{Conclusion}

Based on the study's objective and methods adopted for the study, it was observed that the multinational oil corporations have reached out to their host communities through various sustainable programmes that centre round economic empowerment of the host community members, peace building and infrastructural development in their area of operations. But as good as these programmes are, the study revealed that the sustainable development programmes did not comply with the principles of corporate integrity because the programmes did not meet the needs of the host communities in their area of operations.

Furthermore, the study revealed that the operations of the multinational oil corporations in Niger Delta did not comply with the principle of corporate integrity because of the effect of environmental degradation that occur as a result of the oil exploration activities of the multinational oil corporations.

\subsection{Recommendations}

Development strategies must be people-centred and designed specifically to meet the needs of the Niger Delta indigenes, paying particular emphasis on those already displaced as a result of the oil exploration activities. This would help to allow the indigenes to take an active and influential role in decisions that affect their lives and also change the mindset and prevalence of the attitude of kidnappers and conflict - escalators amongst the various groups operating in the region.

There should be rules and regulations that regulate the oil exploration activities of the multinational oil, through this they will be compel to adhere strictly to the principle of corporate integrity.

\section{References}

Ahiauzu, A. I. (2003). The role of integrity in total quality healthcare Delivery management, CIMRAT Working Paper Series, 3, 1-10, Port Harcourt: International Centre for Management Research and Training.

Ahiauzu, A. I. (2005). Industrial Conflict, CIMRAT Working Paper Series, 5, 1-15, Port Harcourt: International Centre for Management Research and Training.

Asawo, S. P. (2011). Corporate Integrity and Company - Community Conflict Management in the Niger Delta Region of Nigeria. Journal of Leadership, Accountability and Ethics, 8(3), 77-88. Retrieved from http://www.mendeley.com

Darah, G. G. (2001). The socio - economic and political challenges of Niger Delta. In Ozo - Eson, P. I., \& Ukiwo, U. (Eds.), The Niger Delta Development Commission: Towards Development Blueprint. Port Harcourt: Centre for Advanced Social Science.

Efemini, A. O. (2002). A critical reflection on development rights in the Niger Delta. In Wokocha, R. A. (Eds.), Challenges of the Niger Delta, Schalesworths. Port Harcourt: Centre for Democracy and Development.

Eilbert, H., \& Parket. (2001). The Practices of Business: The Current State of Corporate Social Responsibility Business Horizons, August. Pp. 5- 14. Retrieved from www.sciencedirect.com

Ejiofor, P. N. O. (1987). Management in Nigeria: Theories and issues. Onitcha: Africana-Fep Publishers Limited.

Ekuerhare, B. (2002). Sustainable development model for Niger Delta region. In Ozo - Eson, P. I., \& Ukiwo, U. (Eds), the Niger Delta Development Commission: towards Development Blueprint. Port Harcourt: Centre for Advanced Social Science (CASS).

Fajana, S. (2005). Industrial Relations in the Oil Industry in Nigeria. Retrieved from http://unilag.academia.edu/SolaFajana/Papers/612907

Fubara, B. A. (2002). The politics of the Niger Delta. In Ozo - Eson, P. I., \& Ukiwo U. (Eds.). The Niger Delta Development Commission: Towards Development Blueprint. Port Harcourt: Centre for Advanced Social Science (CASS).

Goulet, D. (1998). Tasks and methods in Development Ethics. Cross Currents, 38(2), 24 -32. Retrieved from http://hdr.undp.org 
Henkin, A. B., Cistone, P. J., \& Dee, J. R. (2000). Conflict management strategies of principals in site- based managed schools. Journal of Educational Administration, 38(2), 142-158. Retrieved from http://dx.doi.org/10.1108/09578230010320109

Ivancevich, M. J., Lorenzi, P., Skinner, J. S., \& Crosby, P. B. (1997). Management: Quality and Competitiveness. Boston: the McGraw - Hill Companies Inc.

Jones, I. W., \& Pollitt, M. G. (1995). Economics, ethics and integrity in business. Journal of the Association of Christian Economist, 19(2), 32 -43.

Kaptein, M., \& van Reenen, P. (2001). Integrity management of police organizations, Policing. An International Journal of Police Strategies and Management, 24(3), 281-300. Retrieved from www.emeralddinsight.com

Niger Delta Environmental Survey - NDES. (1992). Niger Delta Environmental Survey - Final Report Phase I (Vol. I) ERML, Lagos. Niger Delta Environmental Survey Phase One Reports, 114.

Odoemena, A. (2011). Social Consequencies of Environmental Change in the Niger Delta of Nigeria. Journal of Sustainable Development in Africa, 11(2), 123-135. Retrieved from www.jsd-africa.com

Ogbogbo, C. (2004). Niger Delta and the resource control conflict 1960 -1995. Unpublished Doctoral thesis in Department of History University of Ibadan, Nigeria.

Owolabi, K. A., \& Owolabi, O. (2009). Corporate Social Responsibility and the Crisis of Development in Africa. Journal of Sustainable Development in Africa, 10(4). Retrieved from www.jsd-africa.com

Secretan, L. (2001). Secrets to making amazing profits: role of personal integrity in corporate culture, Industry. Retrieved from www.secretan.com

Skjaerseth, J. B., Tangen, K., Swanson, P., Christiansen, A. C., Moe, A., \& Lunde, L. (2004). Limits to Corporate Social Responsibility: Report 7/2004 Fridtjoof Nansen Institute. Retrieved from http://www.fni.no/doc\&pdf/FNI.R0704.pdf

Tuschl, R. H., \& Ejibunu, H. T. (2007). EPU Research paper on Nigeria's Niger Delta Crises; Root Causes of Peacelessness. Issue 07/07. Retrieved from http://epu.ac.at/fileadmin/downloads/research/rp_0707.pdf

Werhane, P., \& Freeman, R. (1997). Encyclopedic Dictionary of Business Ethics. Cambridge, MA. Blackwell. Retrieved from http://plato.stanford.edu/entries/ethics-business/

Zalik, A. (2004). Niger Delta: "Petro Violence and Partnership development". Review of African Political Economy, 31(1), 401-424. Retrieved from http://dx.doi.org/10.1080/03056240420005512 